\title{
Fundamental aspects of waste sewage sludge treatment: Microbial solids biodegradation in an aerobic thermophilic semi-continuous system
}

\author{
G. Hamer and C. A. Mason, Zürich
}

\begin{abstract}
The solubilization and biodegradation of whole microbial cells by an aerobic thermophilic microbial population was investigated over a $72 \mathrm{~h}$ period. Various parameters were followed including total suspended solids reduction, changes in the dissolved organic carbon, protein and carbohydrate concentrations, and carboxylic acid production and utilisation. From the rates of removal of the various fractions a simple model for the biodegradation processes is proposed and verified with respect to acetic acid production and utilization, and total suspended solids removal. The process is initiated by enzymic degradation of the substrate microbe cell walls followed by growth on the released soluble substrates at low dissolved oxygen concentration with concommitant carboxylic acid production. Subsequent utilization of the unbranched, lower molecular weight carboxylic acids allows additional energy supply following exhaustion of the easily utilisable soluble substrate from microbial cell hydrolysis.
\end{abstract}

\section{List of symbols}

$Y_{X p / X s} \quad \mathrm{~kg} / \mathrm{kg}$ yield process microbes on substrate yeast cells

$Y_{X p / A c} \quad \mathrm{~kg} / \mathrm{kg} \quad$ yield process microbes on acetate

$Y_{A c / S i} \quad \mathrm{~kg} / \mathrm{kg}$ yield acetate produced by process microbes growing on substrate yeast cells

$Y_{S s / X s} \quad \mathrm{~kg} / \mathrm{kg}$ yield soluble substrate from lysis of yeast cells

$Y_{S s / X_{p}} \quad \mathrm{~kg} / \mathrm{kg} \quad$ yield soluble substrate from lysis of process microbes

$Y_{P / X s} \quad \mathrm{~kg} / \mathrm{kg} \quad$ yield particulates from lysis of yeast cells

$Y_{P / X_{P}} \quad \mathrm{~kg} / \mathrm{kg}$ yield particulates from lysis of process microbes

$\mu_{\max \left(S_{s}\right) \quad \mathrm{h}^{-1} \quad \text { maximum specific growth rate constant for }}$ growth of process microbes on soluble substrate

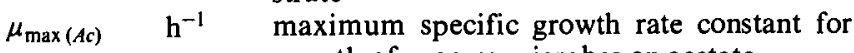
growth of process microbes on acetate

$K s_{S s} \quad \mathrm{~kg} / \mathrm{m}^{3}$ saturation coefficient for growth of process microbes on soluble substrate

$K s_{A c} \quad \mathrm{~kg} / \mathrm{m}^{3}$ saturation coefficient for growth of process microbes on acetate

$K_{d} \quad \mathrm{~h}^{-1}$ death/lysis rate constant for process microbes

$K_{i} \quad \mathrm{~kg} / \mathrm{m}^{3}$ inhibition constant for growth of process

$\begin{array}{lll}K_{L} & \mathrm{~h}^{-1} \quad \text { microbes on acetate } \\ K_{h} & \text { lysis rate constant for whole yeast cells }\end{array}$

$K_{h} \quad \mathrm{~h}^{-1} \quad$ hydrolysis rate constant for particulate biomass

\section{Introduction}

The enforcement of increasingly stringent environmental legislation in many countries has resulted in increased capacity for both municipal sewage and industrial wastewater treatment by combinations of mechanical, biological and physico-chemical process technology. The major result of this situation is an ever increasing quantity of waste sludge, which presents a serious ultimate disposal problem. Policies which allow the dumping/spreading of untreated sludge both on land and at sea are increasingly subject to criticism, necessitating the development of effective sludge treatment technologies. Effective sludge treatment requires the stabilization of biodegradable matter in the sludge and the removal of potentially pathogenic organisms and toxic chemicals from the sludge. Conventional waste sludge treatment involves mesophilic anaerobic digestion, a technology which poses questions with respect to its effectiveness for the removal of pathogens and some toxic chemicals [1]. Microbes, including pathogens originally present in raw sewage and wastewater, are a major constituent of waste sludge and the biodegradation of such particulate matter is the key to effective stabilization and/or hygienization. Aerobic thermophilic processes have been proposed either as a pre-treatment stage prior to conventional anaerobic mesophilic digestion [2] or as a complete sludge treatment [3].

The work reported here concerns the process biology of a semi-continuous, laboratory-scale bioreactor in which microbial solids are undergoing solubilization and biodegradation under aerobic thermophilic conditions. In order to have a standardized feedstock, pressed bakers yeast was used.

\section{Theoretical}

The dissolution of solids in agitated batch reactors has, since the theoretical analysis [4] and experimental verification thereof [5] by Hixson and Crowell, been considered to 
follow the cube root law. In the case of cellulose particles, which are solubilized by enzymic hydrolysis, Humphrey and co-workers [6-8] have proposed a complex shrinkingsite model, which incorporates both inhibition and repression, but ultimately predicts modified cube root law type dissolution. In the case of the enzymic hydrolysis of microbial cells prior to their utilization as carbon energy substrates by the microbes responsible for their hydrolysis, the cube root law is inapplicable, because here the enzymic hydrolysis involves either puncturing or bursting of the substrate microbe cell walls, processes that depend on point attack and point strength of the substrate microbes.

For purposes of modelling the system under investigation here, the following processes are assumed to be occurring:

1. A feed cell population consisting of intact yeast cells is added to a culture containing thermophilic process microbes.

2. The thermophilic process microbes produce extracellular enzymes which are capable of cleaving the cell wall of the yeast. Enzymes attach to the yeast cells in a non-specific distribution over the entire surface.

3. Cell wall lysis occurs at random locations on the yeast cells resulting in release of the soluble cytoplasmic components of the substrate particulates. Lysis results after a minimum of one site cleavage in the wall but may require multiple site cleavage before the wall is sufficiently weak to lyse.

4. Thermophilic process microbes utilize the released soluble substrates as carbon and energy source and in so doing produce acetate as a result of the low dissolved oxygen concentration. Further lysis of remaining whole yeast cells supplies a constant source of soluble nutrients for the thermophilic process microbes. Enzymic degradation of the yeast cell wall polymers supplements this supply.

5. After a significant period, the rate of supply of soluble substrates from yeast cell lysis slows down and the thermophilic microbes begin to utilize the now accumulated acetate to support growth and energy requirements. Additionally, any remaining wall particulates are hydrolysed to soluble energy substrates.

\section{Mathematical description}

The mathematics of this process are based on the following molar stoichiometry.
The elemental composition of yeast cells is assumed to be the same as that for thermophilic microbes and is expressed above on a nitrogen and ash free basis. For the gramme yield coefficients a molecular weight of $27 \mathrm{~g}$ was assumed for 1 mole of cells inclusive of nitrogen and ash. Thus from the above coefficients, yield values $(\mathrm{kg} / \mathrm{kg})$ of thermophilic microbes and acetate from yeast cells would be 0.3 and 0.52 , respectively.

In order to describe growth of thermophilic microbes, Monod kinetics were assumed for growth on yeast cell lysate and Monod kinetics with an inhibition term for growth on acetate, i.e.,

$\mu(S s)=\frac{\mu_{\max (S s)} \cdot S s}{K s_{S s}+S s}$,

$\mu(A c)=\frac{\mu_{\max (A c)} \cdot A c \cdot K_{i}}{\left(S s+K_{i}\right)\left(A c+K s_{A c}\right)}$.

The remaining rate expressions i.e., for yeast cell lysis, for process microbe death/lysis, and for particulate hydrolysis, have been assumed to be first order due to lack of information regarding the kinetics of such processes. In the case of the particle hydrolysis rate constant the use of first order kinetics can be justified for reasons discussed by Eastman and Ferguson [9].

From this basic consideration, a stoichiometric matrix can be constructed for the five parameters, $X_{p}$ (process microbes), $X_{s}$ (feed yeast cells), $S s$ (soluble substrate concentration from lysed yeast cells), $\boldsymbol{P}$ (particulate materials released from cells as a result of lysis, e.g., cell wall fractions) and $A c$ (acetate). The stoichiometric matrix is shown in Table 1.

From this, the following material balances can be described:

$$
\begin{aligned}
X_{p}: \frac{d X_{p}}{d t}= & \mu(S s) \cdot X_{p}-K_{d} \cdot X_{p}+\mu(A c) \cdot X_{p}, \\
X_{s}: \frac{d X_{s}}{d t}= & -K_{L} \cdot X_{s} \\
S s: \frac{d S s}{d t}= & Y_{S s / X s} \cdot K_{L} \cdot X_{s}+K_{h} \cdot P \\
& -\frac{\mu(S s) \cdot X_{p}}{Y_{X p / S s}}+Y_{S s / X p} \cdot K_{d} \cdot X_{p}, \\
P: \frac{d P}{d t}= & Y_{P / X s} \cdot K_{L} \cdot X_{s}-K_{h} \cdot P+Y_{P / X s} \cdot K_{d} \cdot X_{p} \\
A c: \frac{d A c}{d t}= & \frac{Y_{A c / S s} \cdot \mu(S s) \cdot X_{p}}{Y_{X p / X s}}-\frac{\mu(A c) \cdot X_{p}}{Y_{X p / A c}} .
\end{aligned}
$$

$\begin{array}{lll}\mathrm{CH}_{1.8} \mathrm{O}_{0.43}+1.12 \mathrm{O}_{2} \rightarrow & 0.3 \mathrm{CH}_{1.8} \mathrm{O}_{0.43}+0.24 \mathrm{CO}_{2}+0.23 \mathrm{CH}_{3} \mathrm{COC} \\ \text { Yeast cells } & \begin{array}{l}\text { Thermophilic } \\ \text { microbes }\end{array} \\ \mathrm{CH}_{3} \mathrm{COOH}+2.36 \mathrm{O}_{2} \rightarrow & 0.38 \mathrm{CH}_{1.8} \mathrm{O}_{0.43}+1.62 \mathrm{CO}_{2}+3.32 \mathrm{H}_{2} \mathrm{O} \\ \text { Acetate } & \begin{array}{l}\text { Thermophilic } \\ \text { microbes }\end{array}\end{array}$

$\mathrm{CH}_{1.8} \mathrm{O}_{0.43}+1.12 \mathrm{O}_{2} \rightarrow 0.3 \mathrm{CH}_{1.8} \mathrm{O}_{0.43}+0.24 \mathrm{CO}_{2}+0.23 \mathrm{CH}_{3} \mathrm{COOH}+0.48 \mathrm{H}_{2} \mathrm{O}$

Thermophilic
microbes 
Table 1. Stoichiometric matrix for aerobic thermophilic biodegradation processes

\begin{tabular}{lllllll}
\hline & $X_{p}$ & $X_{s}$ & $S s$ & $P$ & $A c$ & \\
\hline Process & & & & & $\begin{array}{l}\text { Reaction } \\
\text { rate }\end{array}$ \\
$\begin{array}{l}\text { 1. Substrate cell } \\
\text { lysis }\end{array}$ & 0 & -1 & $Y_{S s / X s}$ & $Y_{P / X s}$ & 0 & $K_{L} \cdot X_{s}$ \\
$\begin{array}{l}\text { 2. Particle } \\
\text { hydrolysis }\end{array}$ & 0 & 0 & +1 & -1 & 0 & $K_{h} \cdot P$ \\
$\begin{array}{l}\text { 3. Growth on lysis }+1 \\
\text { products }\end{array}$ & 0 & $-1 / Y_{X p / S s}$ & 0 & $\frac{+Y_{A c / S s}}{Y_{X p / S s}}$ & $\mu(S s) \cdot X_{p}$ \\
$\begin{array}{l}\text { 4. Process microbe }-1 \\
\text { death/lysis }\end{array}$ & $0+Y_{S s / X p}$ & $+Y_{P / X p}$ & 0 & $K_{d} \cdot X_{p}$ \\
$\begin{array}{l}\text { 5. Growth on } \\
\text { acetate }\end{array}$ & +1 & 0 & 0 & 0 & $\frac{-1}{Y_{X p / A c}}$ & $\mu(A c) \cdot X_{p}$ \\
\hline
\end{tabular}

Note: As the stoichiometry is incomplete, i.e., $\mathrm{CO}_{2}$ and $\mathrm{O}_{2}$ are not considered, the matrix is not balanced

\section{Materials and methods}

Bioreactor and operating conditions. A $1.5 \mathrm{dm}^{3}$ bioreactor (Bioengineering AG, Wald, $\mathrm{CH}$ ) with full measurement instrumentation, i.e. $\mathrm{pH}$, dissolved oxygen concentration, temperature and impellar speed monitoring, was used for the experiments. Air $\left(6 \mathrm{dm}^{3} / \mathrm{h}\right)$ was sparged into the bioreactor which was operated with an impellar speed of $15 \mathrm{~s}^{-1}$. The operating temperature was maintained constant at $60^{\circ} \mathrm{C}$ and the working volume was $1,300 \mathrm{~cm}^{3}$. The $\mathrm{pH}$ was not controlled.

Aerobic thermophilic culture and feed. Aerobic thermophilic microbes were obtained from an operating municipal waste sludge thermophilic aerobic digestor (UTB, Umwelttechnik Buchs AG, Buchs/SG, CH). Pressed bakers yeast $\left(40 \mathrm{~kg} / \mathrm{m}^{3}\right)$ as the sole biodegradable carbon and nitrogen source was suspended in a nutrient solution containing $\mathrm{KH}_{2} \mathrm{PO}_{4}, \quad 8 \mathrm{~kg} / \mathrm{m}^{3} ; \quad \mathrm{K}_{2} \mathrm{HPO}_{4}, \quad 5.7 \mathrm{~kg} / \mathrm{m}^{3}$; $\mathrm{ZnO}, 3.26 \cdot 10^{-3} \mathrm{~kg} / \mathrm{m}^{3} ; \mathrm{FeCl}_{3} \cdot 6 \mathrm{H}_{2} \mathrm{O}, 43.2 \cdot 10^{-3} \mathrm{~kg} / \mathrm{m}^{3}$; $\mathrm{MnCl}_{2} \cdot 4 \mathrm{H}_{2} \mathrm{O}, 16 \cdot 10^{-3} \mathrm{~kg} / \mathrm{m}^{3} ; \mathrm{CuCl}_{2} \cdot 2 \mathrm{H}_{2} \mathrm{O}, 1.36 \cdot 10^{-3}$ $\mathrm{kg} / \mathrm{m}^{3} ; \mathrm{CoCl}_{2} \cdot 6 \mathrm{H}_{2} \mathrm{O}, 3.8 \cdot 10^{-3} \mathrm{~kg} / \mathrm{m}^{3} ; \mathrm{H}_{3} \mathrm{BO}_{4}, 0.5 \cdot 10^{-3}$ $\mathrm{kg} / \mathrm{m}^{3} ; \mathrm{MgCl}_{2}, 0.2 \mathrm{~kg} / \mathrm{m}^{3}$. The stock solution was stored at $4{ }^{\circ} \mathrm{C}$ for no longer than 5 days. Start-up was carried out by inoculating $500 \mathrm{~cm}^{3}$ aerobic thermophilic sludge into $800 \mathrm{~cm}^{3}$ of preheated $\left(60^{\circ} \mathrm{C}\right)$ yeast suspension. The reactor was operated on a fill and draw cycle of $50 \%$ withdrawal $/ 50 \%$ addition. Yeast addition was carried out slowly so as not to cause a drop in temperature. A cycle time of 3 days was operated during the period immediately preceding the experiment reported here.

\section{I Analytical}

Dry weight. $5 \mathrm{~cm}^{3}$ samples were centrifuged at $30,000 \cdot \mathrm{g}$ and the supernatant removed. The solids were resuspended in water, poured into tared crucibles and left overnight at $105^{\circ} \mathrm{C}$. They were reweighed after cooling in a desiccator.
Ash. After drying overnight. the crucibles used to determine dry weight were placed in an oven at $600^{\circ} \mathrm{C}$ for at least $5 \mathrm{~h}$, allowed to cool and then reweighed.

Dissolved organic carbon (DOC). Appropriate dilutions of the supernatant were made and the DOC assayed directly on a TOCOR total organic carbon analyser (Maihak AG, Hamburg, D). Inorganic carbon was removed by acidification and sparging with nitrogen.

Yeast cell numbers were assayed by direct microscopic enumeration in a haemocytometer.

Microbial activity was assayed using 2-(p-iodophenyl)3-(p-nitrophenyl)-5-phenyltetrazoliumchloride (INT). $1 \mathrm{~cm}^{3}$ INT $\left(2.0 \mathrm{~kg} / \mathrm{m}^{3}\right.$ aqueous solution) was added to a $5 \mathrm{~cm}^{3}$ sample immediately after removal from the bioreactor and placed in a shaking water bath at $60^{\circ} \mathrm{C}$. After $20 \mathrm{~min}$ incubation, $1 \mathrm{~cm}^{3} 37 \%$ formaldehyde was added to stop the reaction. The solution was centrifuged at $10,000 \cdot g$ and the solids resuspended in $10 \mathrm{~cm}^{3}$ tetrachloroethylene (40 vl-\%)/acetone ( $60 \mathrm{vol}-\%)$ solution. After $30 \mathrm{~min}$ incubation in the dark, the absorption of the extracted formazan was measured at $490 \mathrm{~nm}$.

Protein in cells and in the extraceliular medium was measured using the Biuret method with bovine serum albumin as the standard.

Carbohydrate concentration in cells and in the extracellular medium was measured using the anthrone method with glucose as the standard according to Herbert et al. [10].

$\mathrm{NH}_{4}^{+}-\mathrm{N}, \mathrm{NO}_{2}^{-}-\mathrm{N}$ and $\mathrm{NO}_{3}^{-}-\mathrm{N}$ were measured in the extracellular medium using an automated nitrogen analyser (Skalar Analytical, Breda, NL).

Carboxylic acids. The extracellular medium was assayed for low molecular weight carboxylic acids by acidifying using formic acid and injecting into a gas chromatograph (Shimadzu Corp., Kyoto, J). The column was a GP carbopack c/o $3 \%$ carbowax $20 \mathrm{~m} / 0.1 \% \mathrm{H}_{3} \mathrm{PO}_{4}$, $2.1 \mathrm{~m} \cdot 2.6 \mathrm{~mm}$ glass column. Column temperature-programmed $145^{\circ} \mathrm{C} / 2 \mathrm{~min}$, Rate: $5^{\circ} \mathrm{C} / \mathrm{min}$ Detector, FID.

\subsection{Scanning electron microscopy}

$50 \mathrm{~cm}^{3}$ samples were fixed in glutaraldehyde (4 vol-\%) washed with distilled water and frozen in a thin layer between two copper plates according to the method of Müller et al. [11]. They were then fractured at $-105^{\circ} \mathrm{C}$ and dried at $-80^{\circ} \mathrm{C}$ for $2 \mathrm{~h}$ in a Balzers BAF 300 freeze etching device (Balzers AG, Liechtenstein) as described by Walther et al. [12]. The specimens were rotary shadowed $(5 \mathrm{~nm})$ with carbon and overlayed with platinum carbon $(5 \mathrm{~nm})$ and viewed in a Hitachi S-700 scanning electron microscope (Nissai, Sangyo, J). As a consequence of this preparation method some fracturing of surface cells occurred.

Chemicals. All chemicals used were of analytical grade and supplied by either Fluka AG (Buchs/SG, CH), or Merck AG (Darmstadt, D). 


\section{Results}

In this study, the biodegradation of particulate microbial solids by a mixed thermophilic aerobic microbial culture was investigated. This step, typical of the rate-limiting step in waste sludge biodegradation, was followed in the semi-continuous operation of the process where whole yeast cells were used as a standardized substitute for the complex biopolymeric particulates present in actual waste sludge feeds. The thermophilic microbes in the bioreactor were preconditioned by maintaining the same operating conditions for the immediate period prior to the start of this investigation. At the start of the experiment $50 \%$ of the reactor contents $\left(650 \mathrm{~cm}^{3}\right)$ were removed and $650 \mathrm{~cm}^{3}$ of a yeast suspension in the phosphate and trace element solution were added. The addition was sufficiently slow so as to prevent any decrease in temperature of the bioreactor. The temperature during the entire experimental period, including the change over, was controlled at, and never deviated from, $60^{\circ} \mathrm{C}$. The $\mathrm{pH}$ was not controlled during the experiment and remained constant for the first $24 \mathrm{~h}$ at $\mathrm{pH} 5.9$ (Fig. 1). However, after $24 \mathrm{~h}$ the $\mathrm{pH}$ increased and attained a final value of 7.68 after $72 \mathrm{~h}$. Oxygen was supplied to the bioreactor in air but at a sufficiently slow flow rate as to achieve a low dissolved oxygen concentration. The amount of dissolved oxygen in the bioreactor (\% saturation, where saturation at $60^{\circ} \mathrm{C}$ was $3.03 \mathrm{~kg} / \mathrm{m}^{3}$ ) during the biodegradation process is shown in Fig. 1. The dissolved oxygen concentration was initially very low $(2 \%)$ and decreased further to an undetectable level between 18 and $26.5 \mathrm{~h}$. There followed a slight rise to $1 \%$ after $48 \mathrm{~h}$ and a levelling out at $4 \%$ after $65 \mathrm{~h}$.

Biodegradation was followed with respect to the decrease in total and volatile suspended solids and the results are shown in Fig. 1. The total suspended solid removal rates are shown in Table 2 . The rate approximately doubles after $21 \mathrm{~h}$ operation to $0.64 \mathrm{~kg} /\left(\mathrm{m}^{3} \cdot \mathrm{h}\right)$, subsequently decreasing to a lower value after $48 \mathrm{~h}$. The quantity of solids removed at the end of the experiment represents $77 \%$ of the feed concentration ( $41.4 \mathrm{~g}$ ). Concomitant to the decrease in total and volatile suspended solids, there was an increase in the amount of dissolved organic carbon (DOC). This reached a plateau value of ca. $5.8 \mathrm{~kg} / \mathrm{m}^{3}$ between 24 and $48 \mathrm{~h}$ (see Fig. 1) after which time the level declined.

Since the solids were being biodegraded at a fast rate, especially during the period between 18 and $26.5 \mathrm{~h}$, it was of interest to look at the fate of the particulate feed cells per se to see whether either whole cells were being biodegraded or cell lysis was occurring leaving behind partially intact ghosts composed primarily of cell walls. This was conducted by carrying out light microscope direct

Table 2. Solids removal data

\begin{tabular}{|c|c|c|c|}
\hline \multirow{2}{*}{$\begin{array}{l}\text { Time after } \\
\text { addition of } \\
\text { substrate cells } \\
\text { [h] }\end{array}$} & \multirow{2}{*}{$\begin{array}{l}\text { Solids removal } \\
\text { rate } \\
{\left[\mathrm{kg} /\left(\mathrm{m}^{3} \cdot \mathrm{h}\right)\right]}\end{array}$} & \multicolumn{2}{|c|}{ Solids removed as percentage of } \\
\hline & & $\begin{array}{l}\text { Concentration } \\
\text { at } t_{0} \\
{[\%]}\end{array}$ & $\begin{array}{l}\text { Feed } \\
\text { concentration } \\
{[\%]}\end{array}$ \\
\hline 0 & - & 0 & $27^{\mathrm{a}}$ \\
\hline 18 & 0.33 & 26 & 46 \\
\hline 21 & 0.38 & 31 & 50 \\
\hline 24 & 0.64 & 39 & 56 \\
\hline 26.5 & 0.64 & 46 & 61 \\
\hline 48 & 0.20 & 65 & 74 \\
\hline 72 & 0.03 & 68 & 77 \\
\hline
\end{tabular}

a Reduction of solids due to dilution of feed by bioreactor contents

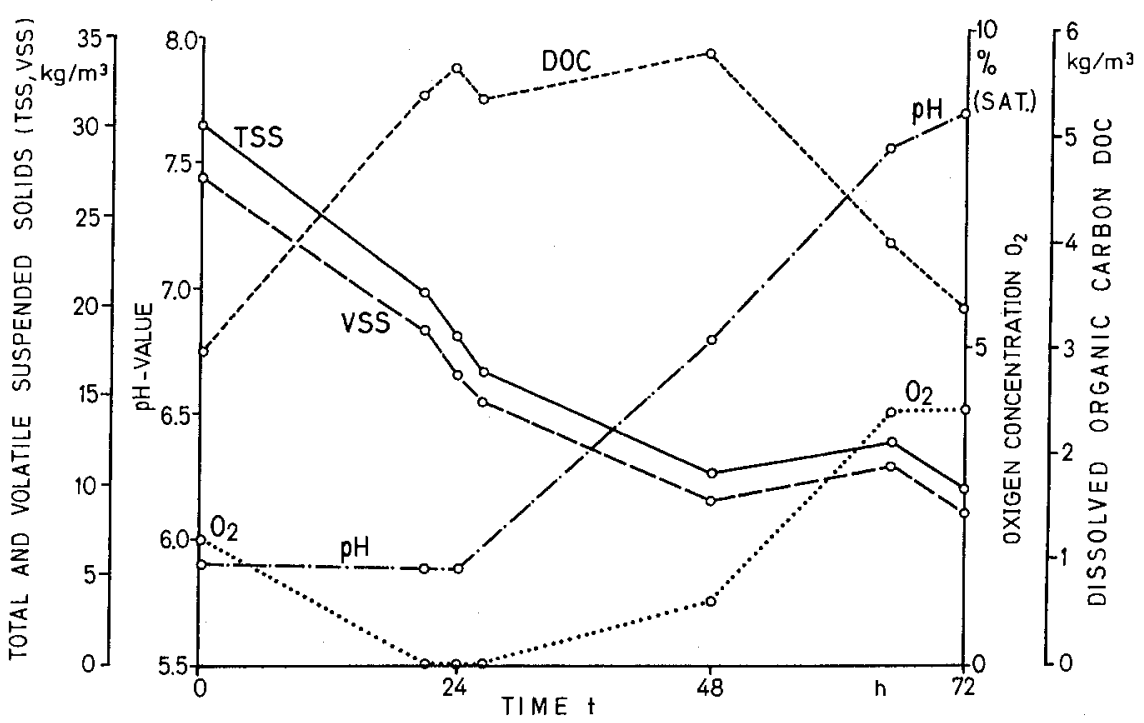

Fig. 1. Changes in concentration of total suspended solids (TSS), volatile suspended solids (VSS), dissolved organic carbon (DOC), $\mathrm{pH}$ and $\mathrm{O}_{2}$ during semi-continuous aerobic thermophilic biodegradation of microbial solids with a cycle time of 3 days 


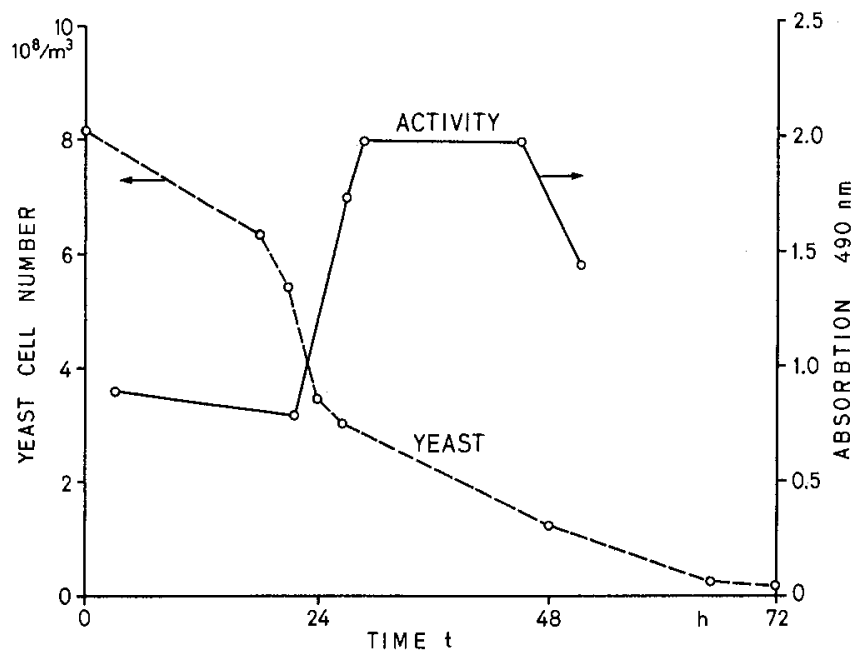

Fig. 2. Changes in process thermophilic aerobic microbe activity and substrate yeast cell number during semi-continuous aerobic thermophilic biodegradation of microbial cells

Table 3. Yeast cell removal data

\begin{tabular}{llll}
\hline $\begin{array}{l}\text { Time after } \\
\text { addition of } \\
\text { substrate cells }\end{array}$ & $\begin{array}{l}\text { Whole yeast } \\
\text { cell removal } \\
\text { rate }\end{array}$ & $\begin{array}{l}\text { Yeast cells removed as percent- } \\
\text { age of }\end{array}$ \\
\cline { 3 - 4 } & & $\begin{array}{l}\text { Cell number } \\
\text { at } t_{0}\end{array}$ & $\begin{array}{l}\text { Cell number } \\
\text { in feed } \\
{[\%]}\end{array}$ \\
{$[\mathrm{h}]$} & {$\left[10^{9} /\left(\mathrm{m}^{3} \cdot \mathrm{h}\right)\right]$} & 0 & $28^{\mathrm{a}}$ \\
\hline 0 & - & 0 & 44 \\
18 & 7.63 & 22 & 52 \\
21 & 23.02 & 33 & 69 \\
24 & 50.54 & 57 & 73 \\
26.5 & 13.23 & 63 & 89 \\
48 & 6.38 & 85 & 98 \\
72 & 0.68 & 98 & \\
\hline
\end{tabular}

a Reduction of yeast cell number due to dilution of feed by bioreactor contents

counts of the yeast cells. The results of these counts are shown in Fig. 2. Noticeable is the very sharp decline in yeast cell numbers during the 18 to $26.5 \mathrm{~h}$ period, paralleling the decrease in total and volatile suspended solids shown in Fig. 1. This decrease in whole yeast cell numbers occurred at a high rate (Table 3 ) particularly between 18 and $26.5 \mathrm{~h}$ where rates 3.5 to $7 \times$ the initial rate were observed. By the end of the experiment, $98 \%$ of the whole yeast cell concentration in the feed had been either partially or totally biodegraded (Table 3 ). This compares to a residual total suspended solids concentration equivalent to $23 \%$ of the substrate solids. This difference can be accounted for by the presence of particulate lysed cell fractions and by the growth of the thermophilic aerobic microbes. Due to their size and thus ease of direct microscopic quantification, yeast cell numbers are easily determined. On the other hand, bacterial cell numbers are not so easily determined due to their morphological diversity and the imposition of a spectrum of nutrient specificities and temperature requirements for accurate quantification [13]. Therefore, a method was used which followed the activity of the bacteria which, whilst being an indirect means of quantification, nevertheless provides the more important information as to what is happening within the bioreactor. As shown in Fig. 2, the activity rises significantly between 18 and $26.5 \mathrm{~h}$ and remains at or above this maximum value between 26.5 and $48 \mathrm{~h}$ until the yeast cells have been almost totally biodegraded. The start of the rise in thermophilic microbial activity occurs simultaneously with the increases in the rate of solids removal and in $\mathrm{pH}$ (Fig. 1). The decline in activity after $48 \mathrm{~h}$ is reflected in the almost insignificant further removal of solids after this time and is also accompanied by a decrease in dissolved organic carbon and an increase in dissolved oxygen concentration.

Direct examination of the biodegradation of yeast cells was carried out using scanning electron microscopy (Fig. 3). It should be noted that the micrographs present qualitative rather than quantitative information as a result of the concentration effects in their preparation procedure. Figure $3 \mathrm{a}$ shows the substrate for the biodegradation process. This is a discretely dispersed suspension of yeast cells with negligible bacterial contamination. After introduction into the bioreactor, the cells are mixed with the thermophilic aerobic microbes (Fig. $3 \mathrm{~b}$ ). The ensuing degradation of yeast cells and growth of process microbes is shown in Fig. $3 \mathrm{c}-\mathrm{e}$. These electron micrographs indicate that a variety of morphological types of microbes are present. Direct evidence for lytic effects is difficult to discern with any degree of confidence, but whilst there is some suggestion that lysis is occurring (see Fig. 3 e) this implies that certainly some of the yeasts seen under the light microscope may be ghosts rather than intact cells. As time progresses in the biodegradation process the yeast cells appear much more irregular and shrunken.

If lysis is occurring, it is unlikely to be as a result of direct contact between the process microbes and the yeast cells: more likely is the release of lytic enzymes from the thermophilic aerobic process microbes. Therefore, it was of interest to examine the variation in the levels of cellular and extracellular protein (Fig. 4). Cellular protein levels (i.e. protein contained in both thermophilic process microbes and yeast cells) decreases constantly during the course of the experiment, whilst the level of extracellular protein remains effectively constant and even exceeds the intracellular concentration after $72 \mathrm{~h}$. The extracellular protein was not differentiated into structural and enzymic fractions and therefore direct evidence of enzymic activity was not obtained. However, as the level of cellular protein decreases, the amount of $\mathrm{NH}_{4}^{+} \mathrm{N}$ released increases (Fig. 4). Both $\mathrm{NO}_{2}^{-}-\mathrm{N}$ and $\mathrm{NO}_{3}^{-}-\mathrm{N}$ concentrations were below detection limits $\left(1 \cdot 10^{-3} \mathrm{~kg} / \mathrm{m}^{3}\right)$.

The cell wall of bakers yeast (Saccharomyces cerevisiae) is composed of approximately equal quantities of 


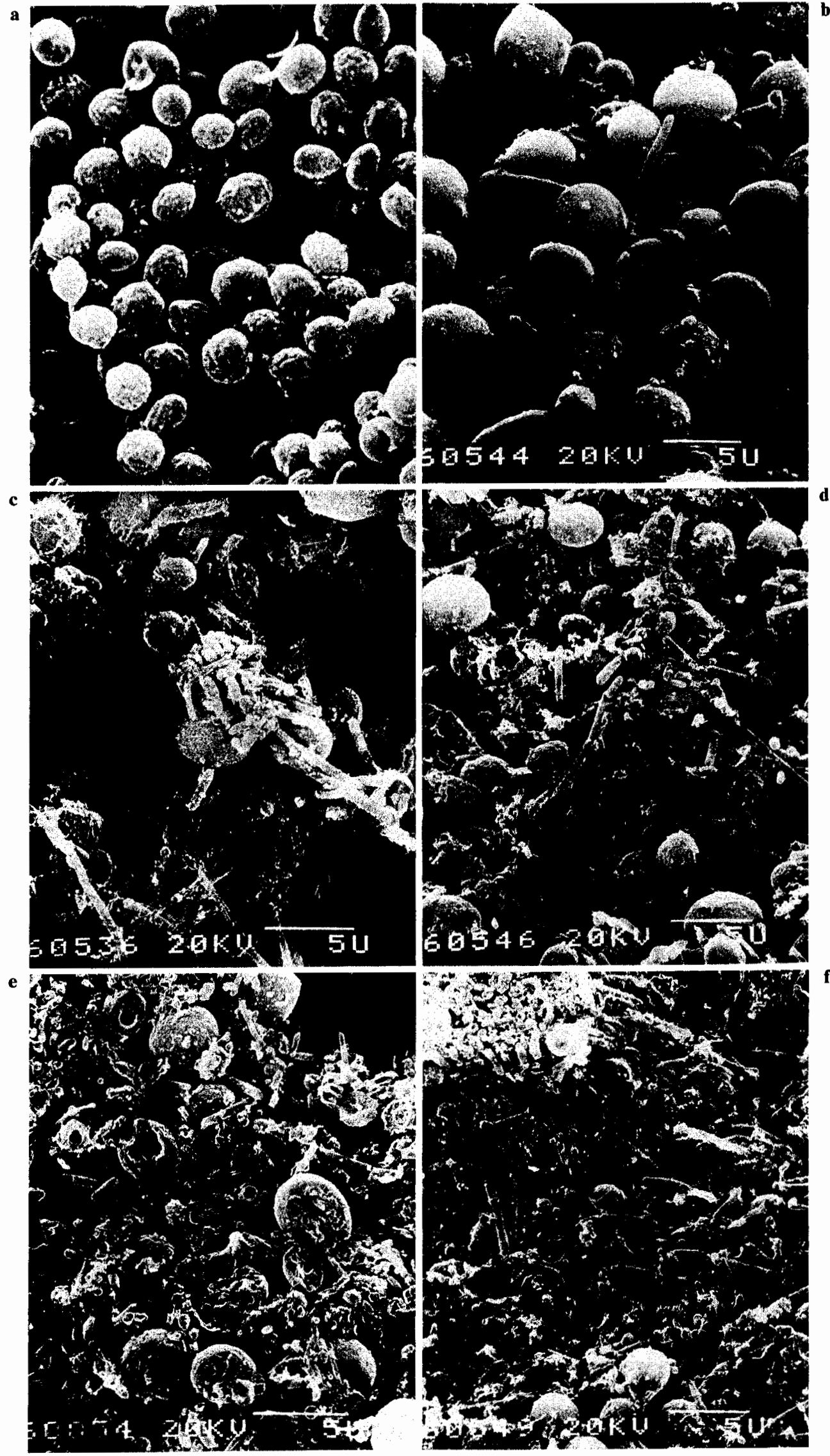




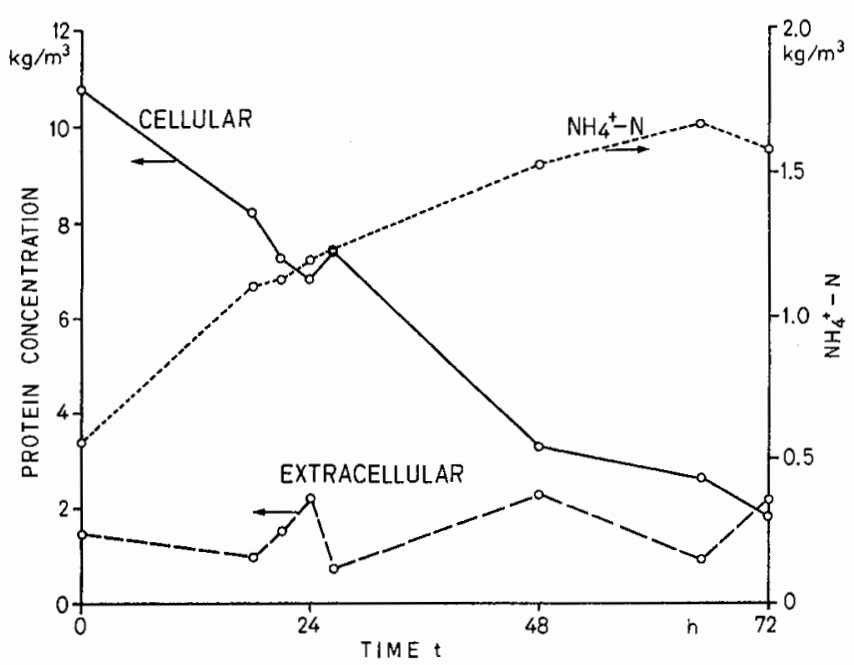

Fig. 4. Changes in cellular and extracellular protein concentrations and of $\mathrm{NH}_{4}^{+}-\mathrm{N}$ during semi-continuous aerobic thermophilic biodegradation of microbial solids. $\mathrm{No} \mathrm{NH}_{4}^{+}-\mathrm{N}$ was added with the yeast cell substrate, released $\mathrm{NH}_{4}^{+}-\mathrm{N}$ being derived from deamination of the particulate nitrogen containing fraction of the biomass

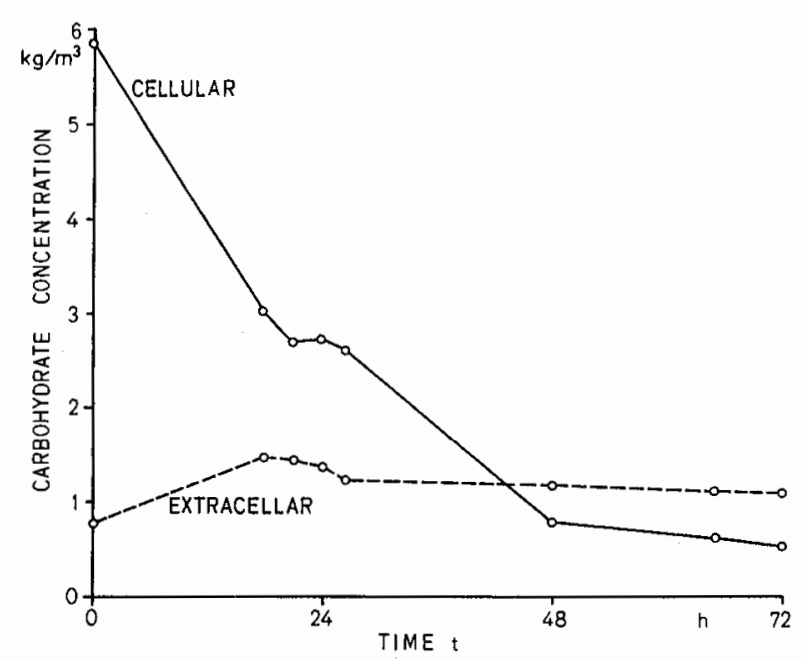

Fig. 5. Changes in cellular and extracellular concentration of carbohydrates during the solubilization and biodegradation of whole yeast cells by aerobic thermophilic microbes

glucan and mannan, both of which are carbohydrates which can often account for about $85 \%$ of the dry weight of the wall [14]. Figure 5 shows the levels of cellular and extra-cellular carbohydrate during the biodegradation of yeast cells. In contrast to the suspended solids and whole yeast cell numbers, the bulk of the carbohydrate is degraded in the first $18 \mathrm{~h}(49 \%)$, with very little activity during the 18 to $26.5 \mathrm{~h}$ period. Between 26.5 and $48 \mathrm{~h}$ further degradation occurs resulting in a final carbohydrate concentration equivalent to only $9 \%$ of the initial.

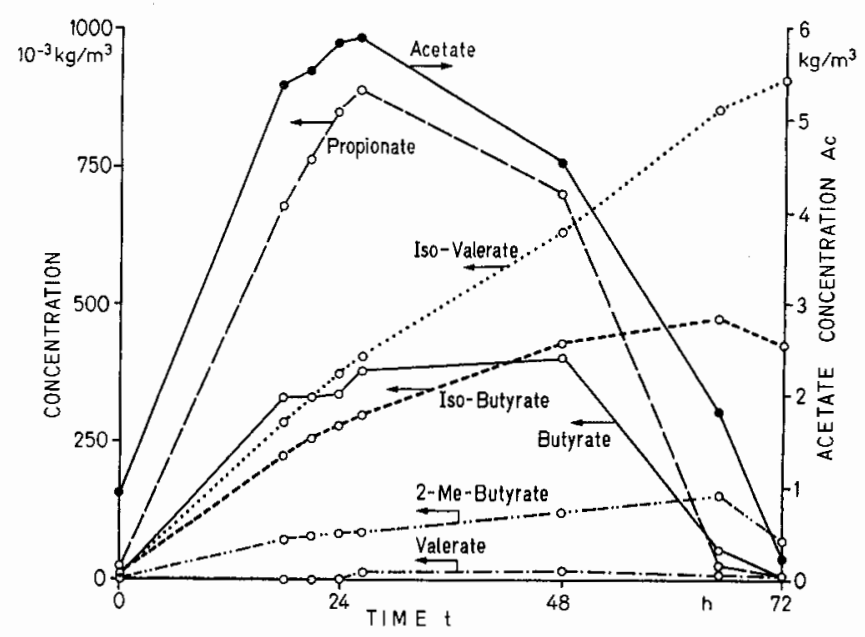

Fig. 6. Variation in the concentration of low-molecular weight carboxylic acids during the biodegradation of whole yeast cells by aerobic thermophilic microbes

Analogous to the extracellular protein level, the extracellular carbohydrate remained effectively constant during the time course.

In order to identify some of the components of the dissolved organic carbon fraction, assays of low molecular weight carboxylic acids were carried out during the biodegradation process. The results, shown in Fig. 6, indicate that most of the DOC was in the form of acetate, which reached a maximum concentration of $5.9 \mathrm{~kg} / \mathrm{m}^{3}$ after $26.5 \mathrm{~h}$. From the data shown in Fig. 6 it appears that the lower the molecular weight and the less branched the molecule the earlier both production and biodegradation occurs. Propionate also peaked at $26.5 \mathrm{~h}$ but at a lower concentration $\left(0.88 \mathrm{~kg} / \mathrm{m}^{3}\right)$. Similarly, butyrate was produced at a still lower concentration and probably reached a maximum between 24 and $48 \mathrm{~h}$, but like acetate and propionate was fully biodegraded after $72 \mathrm{~h}$. Both isobutyric and iso-valeric acids were present in significant quantities after $72 \mathrm{~h}$.

\section{Discussion and Conclusions}

The foregoing results clearly indicate the apparent complexity of the process under consideration. They suggest a sequence of events:

1. Initial degradation of cell wall polymers resulting in the release of soluble cell components, thus the initial slow disappearance in whole yeast cells but fast rate of carbohydrate biodegradation.

2. Accumulation of carboxylic acids, particularly acetic acid, as a result of the low dissolved oxygen concentration, and thus an increase in the dissolved organic carbon concentration. 
Table 4. Values for yield coefficients and kinetic constants used for calculation using the mathematical model

\begin{tabular}{llll}
\hline $\begin{array}{l}\text { Stoichiometric } \\
\text { coefficient or } \\
\text { kinetic constant }\end{array}$ & Value & $\begin{array}{l}\text { Stoichiometric } \\
\text { coefficient or } \\
\text { kinetic constant }\end{array}$ & Value \\
\hline$Y_{X p / X s}$ & 0.30 & $Y_{X p / A c}$ & 0.17 \\
$Y_{A c / S s}$ & 0.52 & $Y_{S s / X s}$ & 0.80 \\
$Y_{S s / X p}$ & 0.80 & $Y_{P / X s}$ & 0.20 \\
$Y_{P / X p}$ & 0.20 & $\mu_{\max (S s)}$ & 0.60 \\
$\mu_{\max (A c)}$ & 0.60 & $K_{S S s}$ & 0.80 \\
$K s_{A c}$ & 0.01 & $K_{d}$ & 0.02 \\
$K_{i}$ & 0.00012 & $K_{L}$ & 0.04 \\
$K_{h}$ & 0.065 & & \\
\hline
\end{tabular}

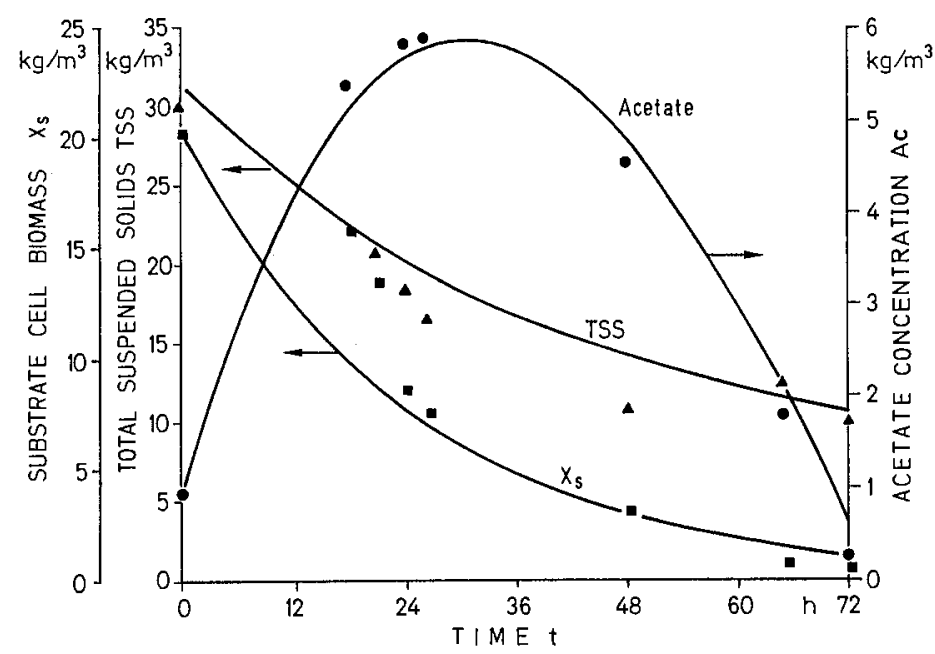

Fig. 7. Comparison of predicted values for acetate concentration $(A C)$ total suspended solids (TSS), and yeast cell biomass $\left(X_{s}\right)$ with experimental values $\left(\boldsymbol{\bullet}, A c ; \boldsymbol{\wedge}, \mathrm{TSS} ; \mathbf{m}, X_{s}\right)$

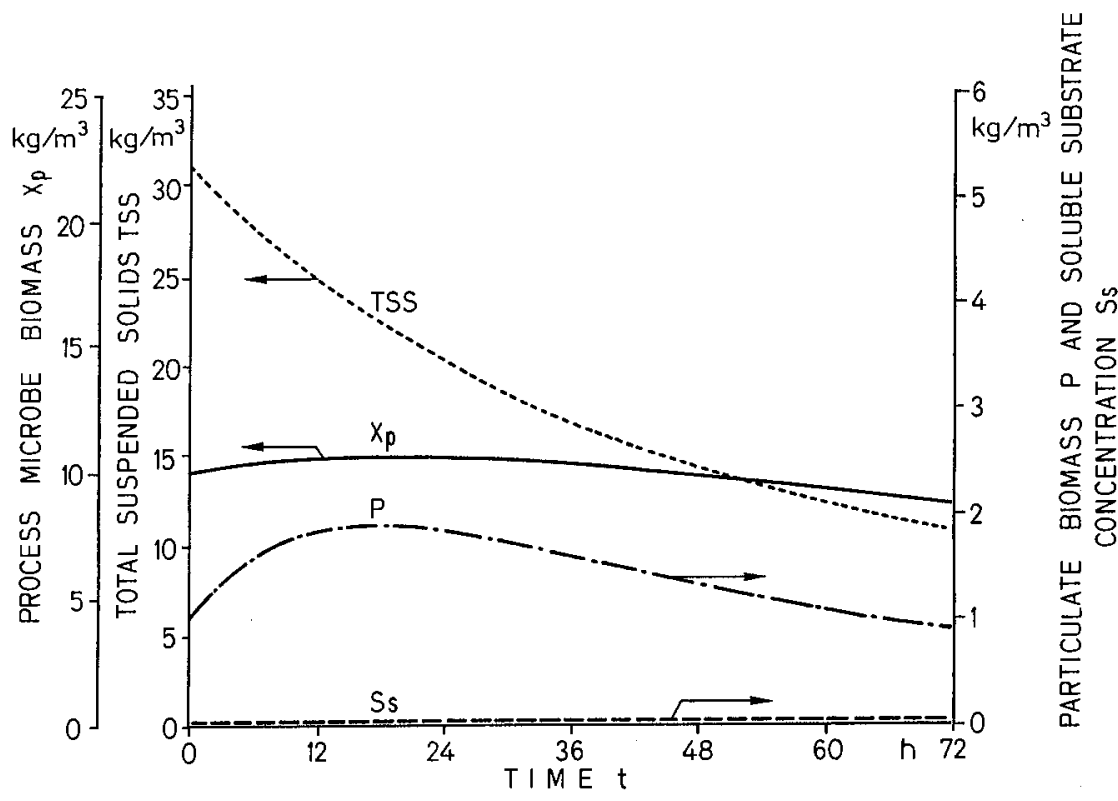

3. Once suitable soluble substrates become available, the process thermophilic microbe activity is enhanced and soluble substrate is preferentially utilized.

4. Exhaustion of the preferred substrate followed by utilisation of low molecular weight carboxylic acids.

5. Hydrolysis of remaining cell wall fragments and utilisation of higher molecular weight carboxylic acids.

If one simplifies this sequence of events by omitting the production of all carboxylic acids other than acetic acid, it should be possible to describe the process by the model presented earlier, provided appropriate values of the constants and yield coefficients in the material balances are selected. On the basis of the values shown in Table 4, the predictions resulting from the model are shown in Figs. 7 and 8 as complete lines. Experimental data, where available, are superimposed as points in these figures. As can be seen, a relatively good fit is achieved, indicating that the simple model proposed is capable of describing the overall process provided a slight degree of simplification is introduced.

The tendency for those carboxylic acids with higher molecular weights than acetic acid to accumulate and subsequently to only degrade towards the end of the batch cycle could be a disadvantage for a sludge treatment process if used in isolation and without subsequent anaerobic stabilization, because the presence of such carboxylic acids would impart malodour to both treated sludge and associated supernatant.

Introduction of new technologies to achieve more efficient process operation require a sound understanding of the fundamental aspects involved. Process optimisation of the thermophilic aerobic sludge treatment technology is now possible knowing the sequence of events involved in microbial solids destruction described here.
Fig. 8. Predicted values for process microbe biomass $\left(X_{p}\right)$ for particulate biomass $(P)$ and soluble substrate concentration. No comparison is made with experimental values due to the absence of this information. The contribution to the total suspended solids is also shown 


\section{Acknowledgements}

We are grateful to Mr. Th. Fleischmann and Mr. C. Lang for their technical assistance and to Dr. E. Wehrli for his time and care in the preparation and examination of the scanning electron micrographs. We would also like to thank Mrs. $\mathrm{H}$. Bolliger for the art work. This work was supported in part by the Swiss National Programme 7D.

\section{References}

1. McEvoy, J.; Giger, W.: Determination of linear alkylbenzenesulfonates in sewage sludge by high-resolution gas chromatography/mass spectrometry. Environ. Sci. Technol. 20 (1986) $376-383$

2. Hamer, G.; Zwiefelhofer, H. P.: Aerobic thermophilic hygienization - a supplement to anaerobic mesophilic waste sludge digestion. Inst. Chem. Eng. Symp. Ser. 96 (1986) 163-180

3. Smith, J. E. Jr.; Young, K. W.; Dean, R. B.: Biological oxydation and disinfection of sludge. Wat. Res. 9 (1975) 17-24

4. Hixson, A. W.; Crowell, J. H.: Dependence of reaction velocity upon surface and agitation: I - Theoretical consideration. Ind. Eng. Chem. 23 (1931) 923-931

5. Hixson, A. W.; Crowell, J. H.: Dependence of reaction velocity upon surface and agitation: II - Experimental procedure in study of surface. Ind. Eng. Chem. 23 (1931) 1002-1009

6. Humphrey, A. E.; Armiger, W. B.; Zabriskie, D. W.; Lee, S. E.; Moreira, A.; Joly, G.: Utilization of waste cellulose for the production of single cell protein. In: Dean, A. C. R.; Ellwood, D. C.; Evans, C. G. T.; Melting, J. (Eds.): Continuous Culture 6: Applications and New Fields, 1976, 85-99

7. Humphrey, A. E.; Moreira, A.; Armiger, W.; Zabriskie, D. Production of single cell protein from cellulose wastes. Biotechnol. Bioeng. Symp. 7 (1977) 45-64
8. Moreira, A. R.; Phillips, J. A.; Humphrey, A. E.: Utilization of carbohydrates by Thermanospora Sp. grown on glucose, cellobiose and cellulose. Biotechnol. Bioeng. 23 (1981) $1325-1338$

9. Eastman, J. A.; Ferguson, J. F.: Solubilization of particulate organic carbon during the acid phase of anaerobic digestion. J. Wat. Poll. Cont. Fed. 53 (1981) 352-366

10. Herbert, D.; Phipps, P. J.; Strange, R. E.: Chemical analysis of microbial cells. In: Methods in Microbiology 7B (Norris, J. R.; Ribbons, D. W.; Eds.) (1971) 209-344

11. Müller, M.; Meister, N.; Moor, H.: Freezing in a propane jet and its application in freeze-fracturing. Mikroskopie (Wien) 36 (1980) $129-140$

12. Walther, P.; Müller, M.; Schweingruber, M. E.: The ultrastructure of the cell surface and plasma membrane of exponential and stationary phase cells of Schizosaccharomyces pombe, grown in different media. Arch. Microbiol. 137 (1980) $128-134$

13. Mason, C. A.; Hamer, G.; Bryers, J. D.: The death and lysis of microorganisms in environmental processes. FEMS Microbiology Reviews 39, 373-401

14. Rose, A. H.: Chemical Microbiology. London: Butterworths 1976

Received August 7, 1986

Prof. Dr. G. Hamer

C. A. Mason

Institute of Aquatic Sciences

Swiss Federal Institute of Technology Zürich

Ueberlandstrasse 133

CH-8600 Dübendorf

Switzerland 


\section{Announcements}

\section{Conference calendar 1987}

March

17.3.-19.3. BIOTEC '87, Düsseldorf, FRG

24.3.-28.3. BioExpo 87 - Exhibition of Biotechnologies applied to Research, Industry and Agriculture, Paris, F

April

1.4.- 8.4. Hannover-Messe INDUSTRIE, Hannover, FRG

13.4.-15.4. BIOTECH 87 - Biotechnology in Clinical Medicine, Rome, I

22.4.-24.4. The Malmö Forum BIOTEKNIK 87, Malmö, S

26.4.-30.4. CEF 87, The Use of Computers in Chemical Engineering, Taormina, I

May

11.5.-19.5. Biotex 87/Agritex 87 - Bio Technology Exhibition for Plant and Vegetable Factories, Tokyo, $J$

12.5.-14.5. BIOTECH 87, London, GB

14.5.-15.5. DECHEMA-Jahrestagung 1987, Frankfurt, FRG
19.5.-23.5. IFAT 87 - 8th International Exhibition for Wastemanagement, München, FRG

June

14.6.-19.6. ECB4 - 4th European Congress on Biotechnology, Amsterdam, NL

22.6.-26.6. 2nd European Conference on Environmental Technology, Amsterdam, NL

July

26.7.-31.7. 10th IFAC World Congress, München, FRG

August

10.8.-14.8. 4th International Conference on Chemistry and Biotechnology of Biologically Natural Products, Budapest, $\mathrm{H}$

September

23.9.-25.9. BioTechnica 1987, Hannover, FRG 